Diabetologia $6,21-26(1970)$

\title{
Observations on the Structure and Function of Liver in Indian Diabetics
}

\author{
H. Vaishnava, P.D. Gulati, V.N. Damodaran \\ Metabolic Unit, Department of Medicine, Maulana Azad Medical College and Associated Irwin and G. B. Pant Hospitals \\ and the Department of Pathology, V.P. Chest Institute, Delhi \\ Received: April 22, 1969
}

\begin{abstract}
Summary. Sixty-three diabetics, (50 growth-onset type "G.O." and 13 maturity-onset "M.O.") and twelve nondiabetic controls, matched for age, sex and nutrition were studied. Hepatomegaly up to $5 \mathrm{~cm}$ was seen in 13 nonketotic, growth-onset and in 2 obese, maturity-onset patients. Mild functional impairment was observed in 7 nonketotic, young diabeties showing increased glycogen deposition. Histologically, glycogen was more marked in young diabetics compared with the maturity-onset diabetics and healthy controls; nuclear glycogen was conspicuously absent in the latter; fatty infiltration was present in 5 obese diabetics and portal cirrhosis was seen in one. The severity of glycogen deposition correlated well with the degree of hyperglycaemia. Quantitatively, glycogen in the liver was high in 15 diabeties (mean $1060 \pm$ $125.5 \mathrm{mg} / 100 \mathrm{~g}$ of the tissue). After prolonged control with insulin, glycogen deposits decreased or remained the same in a few patients studied so far.
\end{abstract}

Observations sur la structure et la fonction du foie chez des diabétiques indiens

Résumé. Soixante-trois diabétiques (50 diabétiques jeunes 《G.O.» et 13 diabétiques d’âge mûr «M. O.») et 12 sujets témoins non-diabétiques, à égalité en ce qui concerne l'âge, le sexe et le régime alimentaire, ont été étudiés. Une hépatomégalie allant jusqu'à $5 \mathrm{~cm}$ a été observée chez 13 diabétiques jeunes non-cétosiques et 2 diabétiques d'âge mûr obèses. Une légère diminution fonctionnelle a été observée chez 7 diabétiques jeunes noncétosiques, présentant un dépôt accru de glycogène. Histologiquement le glycogène était plus abondant chez les diabétiques jeunes que chez les diabétiques d'âge mûr et les témoins; chez ces derniers le glycogène nucléaire était manifestement absent; une infiltration graisseuse a été observée chez 5 diabétiques obèses et une cirrhose portale chez un. La quantité de glycogène accumulé était en corrélation avec le degré d'hyperglycémie. Quantitativement, le glycogène du foie était élevé chez 15 diabétiques (moyenne $1060 \pm 125.5 \mathrm{mg} / 100 \mathrm{~g}$ de tissu). Après un contrôle prolongé par l'insuline, les dépôts de glycogène diminuaient ou restaient les mêmes chez quelques patients étudiés.

Beobachtungen zur Struktur und Funktion der Leber bei indischen Diabetikern

Zusammenfassung. Die Untersuchungen umfaßten 63 Diabetiker ( 50 vom jugendlichen und 13 vom Erwachsenen-Typ) sowie 12 nach Alter, Geschlecht und Ernährung vergleichbare nichtdiabetische Kontrollpersonen. Bei 13 nicht-ketotischen jugendlichen Diabetikern und 2 adipösen Altersdiabetikern fand sich eine Lebervergrößerung bis zu $5 \mathrm{~cm}$. Leichte funktionelle Einschränkungen ließen sich bei 7 nicht-ketotischen jugendlichen Diabetikern mit gesteigerter Glykogeneinlagerung nachweisen. Histologisch fand sich bei den jugendlichen Diabetikern mehr Glykogen als bei den Diabetikern vom Erwachsenen-Typ und den Vergleichspersonen, bei letzteren fiel die Abwesenheit von nuclearem Glykogen auf. Eine Fett. einlagerung bestand bei 5 , eine portale Cirrhose bei einem adipösen Diabetiker. Der Schweregrad der Glykogenspeicherung korrelierte gut mit dem Ausmaß der Blutzuckererhöhung. Bei 15 Diabetikern fand sich quantitativ eine Vermehrung des Leberglykogens mit einem Mittelwert von $1060+125 \mathrm{mg} / 100 \mathrm{~g}$ Gewebe. Die wenigen bisher nach längerer Insulinbehandlung nachuntersuchten Patienten zeigten einen Rückgang oder Gleichbleiben der Glykogenspeicherung.

Key-words: Liver, glycogen deposition, fatty infiltration, function, structure, growth-onset diabetes, maturity-onset diabetes.
Hepatic involvement in diabetes mellitus is well recognized. Marble et al. (1938) and Grey et al. (1945). believed that hepatic abnormalities encountered in these patients were secondary to poor control. During the last two decades, a large number of studies, both experimental and clinical, have been done to find out the effect of diabetes on the structure and function of the liver (Zimmerman et al., 1950; Leevy et al., 1950; Goodman, 1953; Camerini-Davlos et al., 1962; Sarin and Bhu, 1964). Controversy has often arisen with regard to the nature of hepatic involvement in uncontrolled diabetes. Marble et al. (1950), Bondy et al. (1949) and Goodman (1953) demonstrated a variable degree of fatty infiltration causing hepatomegaly, which receded to a considerable extent after the control of the disease. Contrariwise, other workers (Zimmerman et al., 1950; Warren et al., 1966) observed increased glycogen deposition in majority of their patients.
Clinical pattern of diabetes in tropics is quite different from that seen in European countries: nonketotic diabetes occurs more frequently in young adults in this part of the world. So far, very little work has been done to study the liver involvement in diabetics in this region. Few reports published recently have also suggested increased liver glycogen (Sarin and Bhu, 1964; Dube et al., 1965; Damodaran et al., 1966). But these workers have not taken into account the glycogen content of the liver of non-diabetic normal subjects studied under identical conditions, and a quantitative estimation of glycogen in liver tissue has also not been done.

The effect of treatment on these changes also needs to be investigated.

The objectives of the present study were to determine the various histological and functional abnormalities in different forms of diabetes; to correlate the 
severity of histological changes with liver enlargement, degree of hyperglycaemia and functional derangement; finally, to evaluate the effect of treatment with insulin. on liver changes, by repeated biopsies, done at frequent intervals.

\section{Materials and Methods}

Sixty-three untreated or inadequately-controlled diabetics, out of which 50 were growth-onset type, "G.O." (16 ketotic and 34 non-ketotic), and 13 maturityonset type, "M. O." (7 obese and 6 thin), were studied in the Metabolic Unit of the Maulana Azad Medical College and Associate Hospitals, New Delhi, India, over a period of 2 years. The youngest patient was 12 years and oldest 68 years of age; there were 49 males and 14 females. The duration of the disease ranged from 4 months to over 10 years. Twelve non-diabetic subjects, matched for age, sex and nutritional status, were taken as controls. Patients with a past history of chronic alcoholism, viral hepatitis or ingestion of hepatotoxic medicines were excluded from the study.

A thorough clinical examination was done in every case. Particular attention was paid to the presence of hepatomegaly, which was asessed in each case, by palpation and percussion, by more than one observer. Each patient was subjected to a battery of liver function tests, which included estimation of serum proteins by the biuret method (King, 1964), differential protein fractions by serum electrophoresis (Flynn and De Mayo, 1951), thymol turbidity and serum alkaline phosphatase. Bromsulphthalein test was also performed in 20 diabetic and 10 normal subjects, and retention of 5 per cent or more at $45 \mathrm{~min}$ was regarded as abnormal (King, 1964). Liver biopsy was done in fasting state and the specimen was fixed in formol-alcohol. Sections were stained with haemotoxylin and eosin, periodic acid-Schiff and Best-carmine stains and studied for the presence of glycogen, fat, cellular infiltrates, fibrosis, cirrhosis and iron deposits. Glycogen deposits were arbitrarily graded as follows:

Grade I - Glycogen sparsely distributed in the cytoplasm only.

Grade II - Glycogen moderately distributed in the cytoplasm only.

Grade III - Glycogen diffusely distributed in the cytoplasm and sparsely in the nuclei.

Grade IV - Glycogen diffusely distributed in the cytoplasm as well as the nuclei.

Fatty infiltration was also arbitrarily graded as follows:

Grade I - When less than 10\% of the cells showed this change.

Grade II - When 25\% of the cells were involved.

Grade III - When 25\% to 50\% cells were involved.

Grade IV - When more than 50\% cells showed this change.

Quantitative estimation of glycogen in the liver tissue was done in 15 growth-onset, non-ketotic dia- betics and in 10 control subjects of less than 40 years of age, by the method of Kemp et al. (1954). Twenty G.O. diabetics (16 non-ketotic and 4 ketotic) have been subjected to repeated liver biopsies, varying from 2 to 5 times in number, at intervals of 1 month to over a year, after being adequately controlled. Glycogen deposits in the repeat specimens were graded as above and compared with those of the specimen taken before treatment.

Glucagon test, using $1 \mathrm{mg} I . V$., was done to determine the activity of hepatophosphorylase in 15 diabetic and 15 normal controls.

\section{Results}

\section{Prevalence of Hepatomegaly}

Hepatomegaly ranging from 2.5 to $5 \mathrm{~cm}$ was observed in 13 out of 50 G.O. (3 ketotic, 10 non-ketotic) and in 2 obese M. 0 . diabetics. There was no statistically significant difference in the liver size in three groups $(0.10>P>0.20)$. None of the control subjects had liver enlargement.

\section{Liver function tests}

Liver function tests were mildly deranged in $14 \mathrm{pa}$ tients ; 9 belonged to G. 0 . and 5 to M. O. group (Table 1 ). The functional impairment was not proportional to the type and extent of histological changes in the liver.

Table 1. Liver function tests in 63 diabetics

\begin{tabular}{|c|c|c|c|c|}
\hline \multirow[t]{2}{*}{ Tests } & \multicolumn{2}{|c|}{ Growth-onset } & \multicolumn{2}{|c|}{ Maturity-onset } \\
\hline & $\begin{array}{l}\text { ketotic } \\
\text { (16) }\end{array}$ & $\begin{array}{l}\text { non-ketotic } \\
(34)\end{array}$ & $\begin{array}{l}\text { obese } \\
(7)\end{array}$ & $\begin{array}{l}\operatorname{thin} \\
(6)\end{array}$ \\
\hline $\begin{array}{l}\text { Serum proteins } \\
(<6.0 \mathrm{~g} \%)\end{array}$ & 0 & 0 & 0 & $5^{\mathrm{a}}$ \\
\hline $\begin{array}{l}\text { Albumin } \\
(<3.0 \mathrm{~g} \%)\end{array}$ & 0 & 0 & 0 & $5^{a}$ \\
\hline $\begin{array}{l}\text { Thymol turbidity } \\
\text { ( }>4 \text { units })\end{array}$ & 4 & 1 & 0 & 0 \\
\hline $\begin{array}{l}\text { Alkaline phosphatase } \\
\text { (>13 K.A. units) }\end{array}$ & 4 & 3 & 0 & 0 \\
\hline B.S.P. (abnormal) & $2(5)$ & $3(10)$ & $2(3)$ & $0(2)$ \\
\hline
\end{tabular}

a Patients had diabetic nephropathy.

\section{Histological observations}

Histological study showed a variable degree of glycogen deposition in the cytoplasm of liver cells in all cases and in the nuclei in 38 G. O. diabetics (Fig. 1); portal cellular infiltrate was observed in 7 G.O. and fatty infiltration in 5 obese M.O. patients (Fig. 2). Portal cirrhosis (thick-band type) was seen in 1 obese M. O. diabetic. On the other hand, liver specimens from 12 normal subjects showed the presence of intracytoplasmic glycogen only, without any deposition in the nuclei. Glycogen deposition was more marked in diabetics compared with the controls (Table 2). 


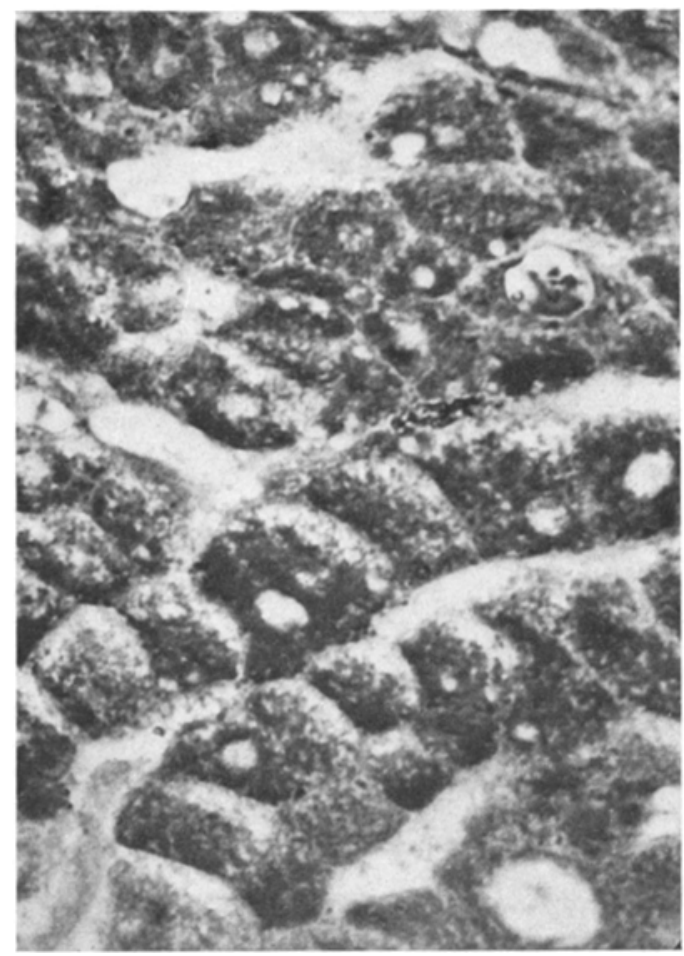

Fig. 1. Liver section of growth-onset, ketotic diabetic (Case No. 18) showing grade IV glycogen infiltration in the cytoplasm and nuclei (Best carmine $\times 450$ )

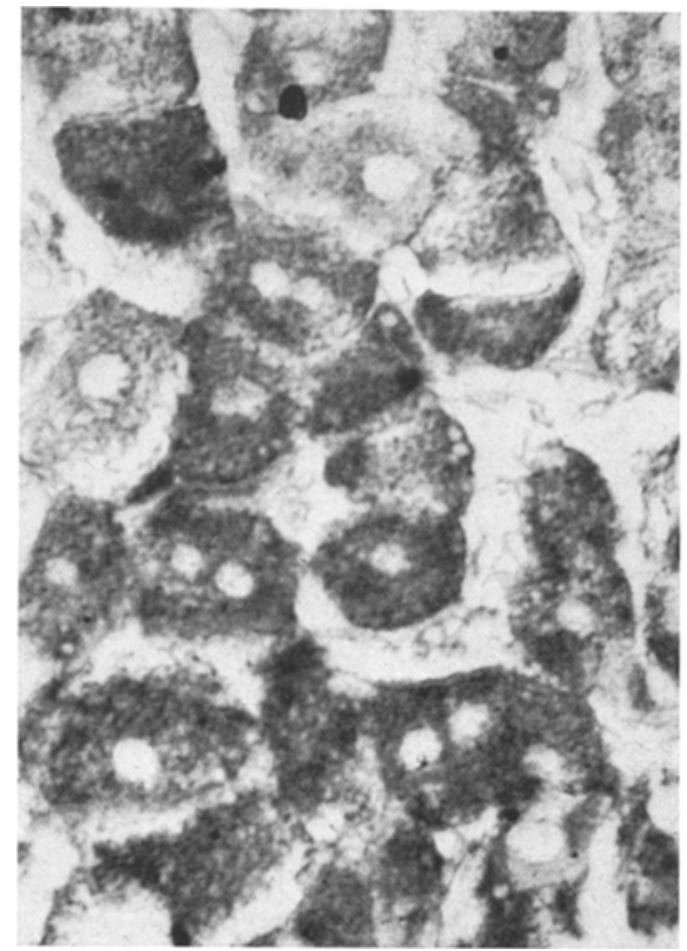

Fig. 3. Liver section of an uncontrolled, growth-onset nonketotic diabetic (Case No. 3) showing grade III glycogen infiltration in the cytoplasm and nuclei before treatment with insulin (Best carmine $\times 450$ )

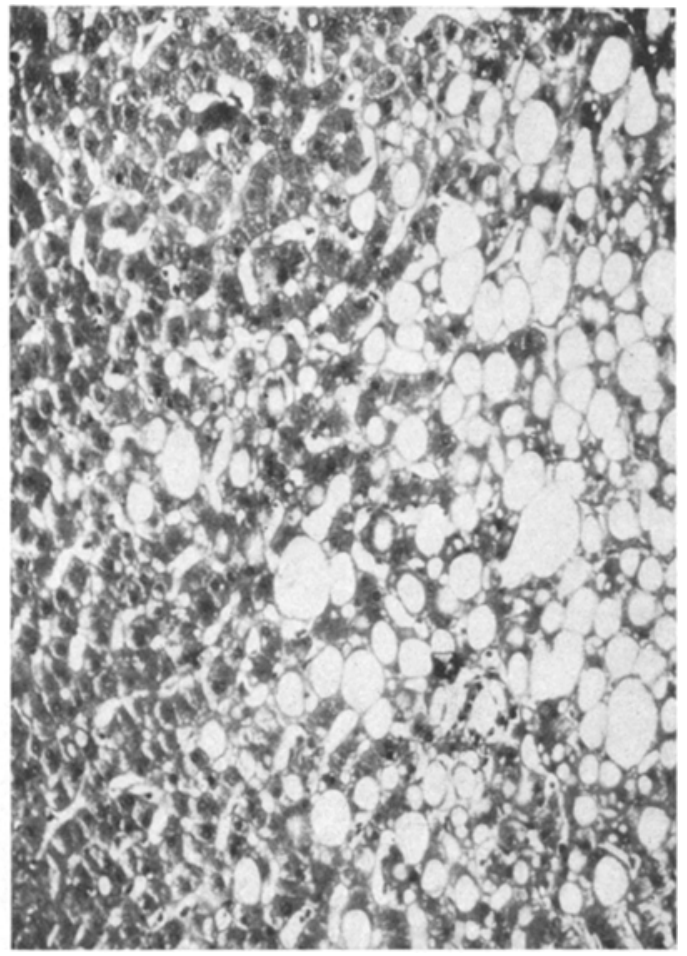

Fig. 2. Liver section of maturity-onset, obese diabetic (Case No. 63) showing grade II fatty infiltration (H \& E $\times 450)$

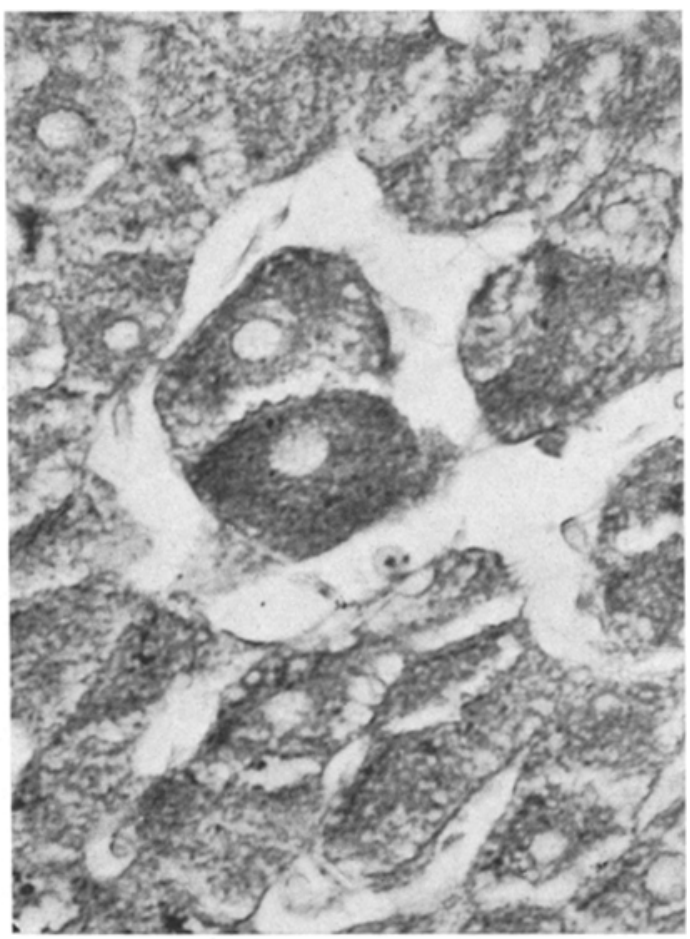

Fig. 4. Liver section of the same case showing only grade I glycogen infiltration in the cytoplasm only after an adequate control of diabetes for a period of one year and 2 months (Best carmine $\times 450$ ) 
Quantitative glycogen estimation in liver tissue

The levels of liver glycogen ranged from 370 to $800 \mathrm{mg} / 100 \mathrm{~g}$ of the tissue (mean $541 \pm 125.8 \mathrm{mg} /$ $100 \mathrm{~g}$ of tissue) in the healthy controls and from 600 to $1800 \mathrm{mg} / 100 \mathrm{~g}$ of tissue (mean $1060 \pm 75.5 \mathrm{mg} / 100 \mathrm{~g}$ of tissue) in the non-ketotic young diabetic subjects in the fasting state. occur in the liver of Indian diabetics. Zimmerman et al. (1950) observed fatty infiltration in 14 out of 28 of their patients, and Goodman (1953) in practically all of his. Such a histological change was seen in this series in only 5 out of 13 cases belonging to the maturityonset type of diabetes; two of whom were obese. Significant morphological change seen in G.O. dia-

Table 2. Histological changes in different types of diabetes

\begin{tabular}{|c|c|c|c|c|c|}
\hline \multirow[t]{3}{*}{ Histological Lesions } & \multicolumn{2}{|c|}{ Growth-onset } & \multicolumn{2}{|c|}{ Maturity-onset } & \multirow[t]{2}{*}{ Controls } \\
\hline & ketotic & non-ketotic & & thin & \\
\hline & $(16)$ & $(34)$ & (7) & $(6)$ & $(12)$ \\
\hline \multicolumn{6}{|l|}{ Glycogen deposits } \\
\hline Grade I & 0 & 0 & 2 & 4 & 4 \\
\hline Grade II & 1 & 2 & 5 & 1 & 7 \\
\hline Grade III & 3 & 29 & 0 & 0 & 1 \\
\hline Grade IV & 12 & 3 & 0 & 1 & 0 \\
\hline \multicolumn{6}{|l|}{ Fatty infiltration } \\
\hline Grade I & 0 & 0 & 1 & 2 & 0 \\
\hline Grade II & 0 & 0 & 2 & 0 & 0 \\
\hline
\end{tabular}

Effect of insulin treatment on liver glycogen

It was observed that glycogen remained unchanged in all patients studied up to 6 months, but decreased in 3 out of 5 after 6 months to 1 year, and in both the subjects after one year of adequate control (Figs. 3 and 4).

\section{Glucagon test}

After I. V. glucagon, the rise in blood sugar within 20 minutes ranged from $28.0 \mathrm{mg} \%$ to $65.5 \mathrm{mg} \%$ (mean $48.5 \mathrm{mg} \%$ ) in 15 diabetics and from $35.4 \mathrm{mg} \%$ to $56.0 \mathrm{mg} \%$ (mean $46.2 \%$ ) in 15 controls. The difference is not significant $(P>0.5)$.

Correlation of hepatomegaly and degree of fasting hyperglycaemia with the severity of hepatic glycogen deposition

All the 13 young patients, having variable liver enlargement, showed Grade III and IV glycogen deposition, and both the M.O. diabetics with hepatomegaly were obese and had Grade II fatty infiltration. Correlation of hyperglycaemia with the severity of glycogen deposition is shown in Table 3. betics was excessive laying-down of glycogen in the liver. The finding of asymptomatic cirrhosis with fatty infiltration in the absence of haemochromatosis in one of our poorly controlled maturity-onset diabetic, is rather interesting. Whether it was coincidental or a consequence of diffuse fatty change is a matter of conjecture. Connor (1938) described fatty infiltration as a precursor of cirrhotic changes in the liver of diabetics. Kalk (1960) in similar studies reported cirrhosis occuring in 26.6 percent of his cases. On the other hand, Creutzfeldt (1959) in his extensive study of the relationship of liver and diabetes concluded that cirrhosis preceded this metabolic disorder in most instances.

Hepatomegaly was comparatively less frequent as well as less marked in our patients. It was seen in 15 out of 63 patients compared with about 60 per cent in the series of Goodman (1953). However, contrary to the observations of Marble et al. (1938), massive hepatomegaly was never encountered in the present study. The cause of hepatic enlargement has been differently explained. Zimmerman et al. (1950) and Goodman (1953) believed it to be due to a diffuse fatty change irrespective of the type of diabetes. Our experi-

Table 3. Correlation of hyperglycaemia to glycogen deposition

\begin{tabular}{llccc}
\hline Glycogen deposition & No. of cases & \multicolumn{4}{c}{ Fasting blood sugar levels $(\mathrm{mg} \%$ ) } \\
\cline { 3 - 5 } & & 100 to 200 & 201 to 400 & 410 to 600 \\
\hline Grade I and II & 15 & 11 & 4 & 0 \\
Grade III & 32 & 3 & 23 & 6 \\
Grade IV & 16 & 1 & 5 & 10 \\
\hline
\end{tabular}

Statistical evaluation significant (F $=29.7$ for $2 \& 59$ D.F., $P<0.01$ ).

\section{Discussion and Conclusions}

It is evident from the foregoing observations that diffuse morphological and mild functional alterations ence has been at variance with theirs: it was entirely due to the glycogen accumulation (Grade III and IV) in young patients, and the fatty change was seen in 2 of the elderly diabetics with hepatomegaly. 
Functional derangement of liver was minimal and was often detected by the more sensitive bromsulphthalein test. Zimmerman et al. (1950) and CameriniDavlos et al. (1962) also made similar observations. Correlating with the histological lesions, the functional impairment was seen in 10 out of 50 young diabetics showing glycogen deposits, and in 2 out of 5 older patients showing predominant fatty change. Studies of Zimmerman et al. (1950) revealed greater prevalence of functional impairment occurring in the presence of fatty infiltration rather than with glycogen deposition.

It is of interest that glycogen deposition occurred in all the diabetics, and that it was in excess of that seen in the normal controls, both qualitatively and quantitatively. Values of liver glycogen in our healthy controls were in the lower range of those reported by Bondy et al. (1949) and Sokal and Gerszi (1959). The difference may be partly explained by nutritional and environmental factors. Ehrlich demonstrated large glycogenfilled vacuoles in the liver cells of diabetic patients as early as 1883 . But subsequent histological and biochemical studies of Bondy et al. (1949) and Hildes et al. (1949) showed a depletion of liver glycogen stores. Most of the studies done during the last two decades have invariably shown increased hepatic glycogen deposition in uncontrolled diabetics (Zimmerman et al., 1950; Sarin and Bhu, 1964; Dube et al., 1965).

The exact mechanism of this glycogen accumulation in the liver of diabeties is not clear, and very little work has been done to investigate it so far. In the present study an attempt has been made to correlate it with the severity of hyperglycaemia. When the two parameters were subjected to statistical evaluation, the results were found to be significant ( $\mathrm{F} 29.7$ for 2 and d.f., $P<0.01$ ). But whether this increased liver glycogen resulted from the same metabolic defect as hyperglycaemia or something else, is very difficult to say at this stage. However, Chipps and Duff (1949) failed to find a correlation between blood sugar levels and glycogen content of the liver. Recent experimental studies in diabetic animals have pointed out that increased glycogen in this disorder is due to the same enzymatic defects as seen in glycogen storage disease (Cahill et al., 1959; Lowe et al., 1962; Yoshatoshi et al., 1967). Enzyme abnormalities leading to increased glycogen synthesis as well as to decreased glycogen breakdown have been demonstrated by these workers. However, the glucagon test done in a few of our patients has indicated the activity of hepatophosphorylase to be comparable with that of the normal subjects. But a study to estimate the activity of various enzymes in the liver of Indian diabeties has yet to be carried out.

In the present study, an attempt has been made to study the effect of treatment with insulin. Divergent opinions have been expressed by Western workers with regard to these findings. Long (1947) believed that insulin, when given in physiologic amounts, inhibited liver glycogen deposition whereas Middleton and Hockaday (1965) observed increased glycogen storage in the liver leading to hepatomegaly if the disease was treated with insulin. Our observations in a few cases indicated that glycogen deposition either remained the same or was decreased to variable extent if the disease was kept adequately controlled for a year. This study is still in progress.

Acknowledgements: We are grateful to Messrs. B.M. Sharma and Manmohan Shanker, of the Metabolic Laboratory of the Maulana Azad Medical College and Associate hospitals, for technical assistance. Our thanks are also due to Mr. G.P. Mathur, statistician, New Delhi Tuberculosis Centre, for help in statistical analysis.

\section{References}

Bondy, R.K., Sheldon, W.H., Evans, L.D.: Changes in liver glycogen studied by needle aspiration technique in patients with diabetic ketosis with a method for estimation of glycogen from histological preparation. J. clin. Invest. 28, 1216-1227 (1949).

Cahill, G. F., Ashman, J., Renold, A.E., Hastings, A.B.: Blood glucose and the liver. Amer. J. Med. 26, 264-282 (1959).

Camerini-Davalos, R., Marble, A., Muench, H.: Liver function in diabetes mellitus. New Engl. J. Med. 266, $1349-1354(1962)$.

Chipps, H.D., Duff, G.L.: Glycogen infiltration of liver cell nuclei. Amer. J. Path. 18, 645-655 (1949).

Connor, C.L.: Fatty infiltration of liver and development of cirrhosis in diabetes and chronic alcoholism. Amer. J. Path. 14, 347-364 (1938).

Creutzfeldt, W.: Clinical relationship between diabetes mellitus and the liver. Acta Hepatosplen. 6, 156-171 (1959).

Damodaran, V.N., Gulati, P.D., Vaishnava, H.: Liver biopsy in diabetes mellitus. Proc. World Congress, 'Diabetes in tropics', p. 125-128, 1956.

Dube, B.K., Mathur, K.S., Wahi, P.N., Kumar, A. : Study of liver structure in diabetes mellitus. J. Ass. Phyens India 13, 323-329 (1965).

Fhrlich, P. (1883): Cited by Warren et al., 1966.

Flynn, F.V., De Mayo, P. : Microelectrophoresis of protein on filter paper. Lancet 1951 II, 235-239.

Goodman, J.I.: Hepatomegaly and diabetes mellitus. Ann. int. Med. 39, 1077-1087 (1953).

Grey, J., Hook, W., Batty, J.L.: Liver function studies in diabetes mellitus Ann. int. Med. 24, 72-79 (1946).

Hildes, J.A., Sherlock, S., Walsh, V.: Liver and muscle glycogen in normal subjects in diabetes mellitus and acute hepatitis. Clin. Sci. 7, 287-297 (1949).

Kalk, H.: The relationship between fatty liver and diabetes mellitus. Germ. med. Monthly 5, 81 -84 (1960).

Kemp, J.A.: Determination of glycogen in the tissue by colorimetric micro-method. Biochem. J. 56, 646-648 (1954).

King, E.J.: Microanalysis in Medical Biochemistry. London: J. \& A. Churchill, 1964.

Leevy, C. M., Ryan, C.M., Fureberg, J.C.: Diabetes mellitus and liver dysfunction - etiologic and therapeutic consideration. Amer. J. Med. 8, 290-299 (1950).

Long, C.N.H., Duncan, G.C.: Disease of metabolism, 2 nd Ed., p. 20. Philadelphia: Saunders 1947.

Lowe, C.W., Sokal, J.E., Mosowich, L.L., Sarcione, E.J., Dorey, B. H.: Studies in liver glycogen disease-effects of glucogaen and other agents in metabolic pattern and clinical status. Amer. J. Med. 33, 4-26 (1962).

Marble, A., White, P., Began, L.K., Smith, R.M.: Enlargement of the liver in diabetic children. Arch. intern. Med. 62, $741-764$ (1938). 
Middleton, G.D., Hockaday, T.D.R.: Glycogen-laden hepatomegaly in diabetes mellitus. Diabetologia 1, $116-127$ (1965).

Sarin, L.R., Bhu, N. : Studies of liver in diabetes of juvenile-onset type. J. Ass. Phyens India 12, 509-514 (1962).

Sokal, J.D., Gerazi, K.E.: Human liver glyeogen levels. J. Lab. clin. Med. 53, 876-881 (1959).

Warren, S.L., LeCompt, P.M., Legg, M. A.: The pathology diabetes mellitus, p. 142 and 299 . Philadelphia: Lea \& Febiger, 1966.

Yoshatoshi, Y., Oka, H., Kaenke, T., Yamashita, K., Oda, T.I.: Glycogen synthesis in alloxan diabetic rat liver, Excerpta Medica-International Congress on Diabetes, p. 268, 1967 .

Zimmerman, H.J., MacMurray, F.G., Rappaport, H., Alpert, L.K.: Studies of liver in diabetes mellitusstructural and functional abnormalities. J. Lab. clin. Med. 36, 912-928 (1950).

Prof. H. Vaishnava

Department of Medicine

Maulana Azad Medical College

and Associated Trwin and

Pant Hospitals

New Delhi, India 